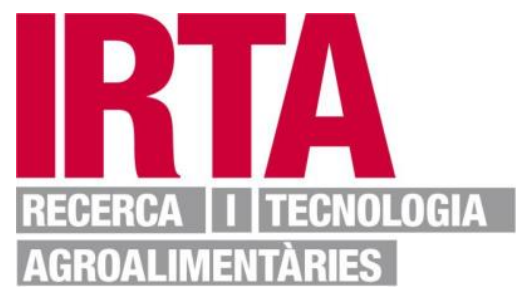

This is the peer reviewed version of the following article: Santos, Alexandre C. A., and Nuno Caiola. 2020. "Environmental Typology Of Rivers From The Brazilian Semiarid As A First Step For The Application Of The Index Of Biotic Integrity: The Case Of The Chapada Diamantina". River Research And Applications. doi:10.1002/rra.3613., which has been published in final form at https://doi.org/10.1002/rra.3613. This article may be used for non-commercial purposes in accordance with Wiley Terms and Conditions for Use of Self-Archived Versions http://www.wileyauthors.com/self-archiving.

Document downloaded from: 


\title{
Environmental typology of rivers from the Brazilian semiarid as a first step for the application of the index of biotic integrity: the case of the Chapada Diamantina
}

\section{Environmental typology of rivers in the Brazilian semiarid}

\author{
A.C.A.Santos ${ }^{1, *} \&$ N.Caiola ${ }^{2}$ \\ ${ }^{1}$ Laboratório de Ictiologia, Departamento de Ciências Biológicas, Universidade Estadual de Feira de \\ Santana, Av. Transnordestina, s/n, 44031-460, Feira de Santana, Bahia, Brasil. \\ ${ }^{2}$ IRTA Marine and Continental Waters. Ctra. Poble Nou km 5.5. 43540 Sant Carles de la Ràpita \\ (Tarragona), Spain. \\ *Corresponding Author: E-mail: alexandreclistenes@gmail.com
}

\begin{abstract}
Defining environmental river types is an essential step in the development of accurate fish-based methods (IBI, Index of Biotic Integrity) to assess the environmental quality of aquatic ecosystems. In this study, the environmental typology of the rivers and streams in the region of Chapada Diamantina was developed. Thirty-five sampling sites representative of the upper Paraguaçu River and its main tributaries were characterized to characterize the fish assemblages and abiotic environmental descriptors. A cluster analysis based on fish species CPUE was performed to define a first biological typology. Then, a discriminant analysis model was developed to select the environmental descriptors that explained the fishbased river types. The model selected eleven environmental variables and classified $91 \%$ of the cases. The river typology defined in this study will be used for the development of an IBI to assess the ecological status of the Chapada Diamantina rivers. It is expected that both the typology developed here and the future IBI will provide important and useful tools to develop and apply nature conservationoriented management schemes in the Chapada Diamantina aquatic ecosystems.

KEYWORDS: river typology, fish, environmental quality, conservation, management
\end{abstract}




\section{INTRODUCTION}

Biotic integrity is the ecosystem ability to support and maintain a balanced, integrated, adaptive community of organisms having a species composition, diversity, and functional organization comparable to that of natural habitat of the region (Karr and Dudley 1981). In running waters, biotic integrity depends mainly on flow, energy input, water quality, biological interactions, and habitat structure (Karr et al. 1986; Hughes and Gammon, 1987; Karr, 1991).

The index of biotic integrity (IBI) (Karr, 1981) influenced the development of almost all fish-based methods to assess human-induced impacts on aquatic ecosystems. Although IBIs have been developed and applied worldwide (e.g. Angermeier \& Karr, 1986; Lyons, 1992; Oberdorff \& Hughes, 1992; Ganasan \& Hughes, 1998; Kamdem Toham \& Teugels, 1999; Joy \& Death, 2004; Rodríguez-Olarte et al., 2006; Casatti et al., 2009), appropriate definition of environmental river types is a major issue in developing regional IBIs (Strange, 1998) because of large-scale natural variability in fish communities (Schmutz et al, 2007). The underlying principle of this approach is that rivers are understood as a sequence of distinct segments with homogeneous abiotic and biotic characteristics and, thus, the entire river network can be classified into distinct types. For each river type, the basic functional unit, undisturbed conditions can be accurately formulated and the deviation from these conditions provide the quantitative measure of the ecological status (Turak \& Koop, 2008). The fish metrics used to measure the deviation from reference conditions are formulated for each river type making them more robust and adequate to respond significantly to human pressures (Steedman, 1988; Daniels et al., 2002; Roset, et al., 2007).

This was the approach used by the European Union Water Framework Directive (WFD, European Commission, 2000) in the development of biotic indices to assess the ecological status of European water bodies. The WFD postulates two options for establishing the typologies, both using strictly abiotic criteria: System A and B (Annex II of the WFD). System A uses fixed categories of three parameters to classify rivers: three altitude ranges, four basin size ranges, and three geological categories. On the other hand, System B proposes to establish river types analyzing different factors considered as obligatory and optional. However, as the hypothesis is the lower the biotic heterogeneity within each type the greater the IBI accuracy (Fausch et al., 1990; Smogor \& Angermeier, 2001), developing environmental typologies without a biological component is considered an inadequate approach. 
An alternative approach for the development of abiotic river environmental typologies that takes into account the biological communities was successfully carried out in the development of IBIs to assess the ecological status of rivers from the Iberian Peninsula that accurately evaluated the ecological status of all river types, from highland rivers to intermittent streams in semiarid zones (Sostoa et al. 2004; Segurado et al. 2014). First a strictly biological typology based on fish assemblages was performed. Then, an analysis of the abiotic descriptors that better explained the biological typology was carried out. At the end, the final product was an environmental typology based on the WFD system B variables but with an underpinning biological river classification.

In the central region of the state of Bahia, in the Brazilian semiarid, typical rock formations develop, where the matrix vegetation is the Caatinga (Brazilian semiarid vegetation). Due to its isolation within the semiarid domain, these rupestrian grasslands, a mosaic of herbaceous and shrubby physiognomies, are characterized by high levels of endemism and the presence of rare species. Areas of rupestrian grass land are located on quartzite or ironstone soils in highlands usually above $900 \mathrm{~m}$ (Harley 1995; Giulietti et al. 1997). From the 19th century until the 1980s, the rivers of the Chapada Diamantina were impacted by mechanized diamond mining and this exploration resulted in drastic changes in the riverbeds and banks due to burning the vegetation and soil excavation. At present, the main impacts are related to the deforestation and unregulated tourism activities (Santos \& Caramaschi, 2011). Notwithstanding the importance and the high incidence of different types of environmental degradation, no studies on the environmental quality of the rivers has been carried out.

Due to the rich and endemic ichthyofauna of the Chapada Diamantina rivers and streams (de Pinna, 1992) and the threats that these aquatic ecosystems were, and still are, subjected to, the evaluation of the ecological status is necessary. Adequate management schemes that ensure nature conservation can only be applied after the completion of an accurate ecological diagnosis carried out with assessment methods capable of detecting human-induced impacts on the aquatic ecosystems. A fish based IBI will definitely provide a useful assessment tool and the first step to develop such a method is to develop a river typology. Due to the high variability of both environment and fish fauna of the Chapada Diamantina rivers and streams, the development of an environmental typology based on both biological communities and abiotic variables would be the most adequate approach. In this study an environmental river typology was defined as a first step for the development of an IBI to assess the ecological status of the rivers and streams from the Chapada Diamantina region in the Brazilian semiarid. 


\section{MATERIALS AND METHODS}

Study area

The study was conducted in the Chapada Diamantina region (state of Bahia, NE Brazil), which is part of the Paraguaçu River basin and contains the rivers and streams that form the source of Paraguaçu River (Fig. 1). The Paraguaçu River is about $500 \mathrm{~km}$ long, from the Chapada Diamantina region to the mouth in the western region of the Todos os Santos bay. This river basin is one of the largest in northeastern Brazil and supports a very rich endemic fish fauna (de Pinna, 1992). The Chapada Diamantina is a mountainous region with an area of $41,751 \mathrm{~km} 2$ and an altitude varying between 400 and $1700 \mathrm{~m}$. The climate is semiarid with maximum rainfall of approximately $175.8 \mathrm{~mm}$, occurring between November and December. Temperatures are milder than in the surrounding regions, with annual averages lower than 22 ${ }^{\circ} \mathrm{C}$ and low winter temperatures, reaching $0{ }^{\circ} \mathrm{C}(\mathrm{CPRM}, 1994)$. Thirty-five river stretches (sampling sites) were selected to cover all the environmental variability along the longitudinal gradient, ranging from rivers at higher altitude and from lower order to larger and more complex rivers located at a lower altitude (Fig 1).

\section{Sampling}

The sampling was carried out from April 2008 to March 2009. In each sampling site a stretch with all representative mesohabitats present (runs, riffles and pools) was selected. Every stretch had a length of 10 times the river width with a minimum of $50 \mathrm{~m}$ long. To sample the fish community two blocking nets of 8 $\mathrm{mm}$ mesh size were settled in the beginning and end of each stretch. Fishes were collected using a standard active method consisting of the use of two sieves on the riverbanks and a beach seine (locally known as "picaré") in the middle of the river channel (Ueida \& Castro, 1999). These sampling methods are suitable and very efficient for rapid ecological or faunistic surveys (Ribeiro \& Zuanon, 2006). The sampling effort was proportional to the river size, allowing the calculation of the catch per unit of effort (CPUE) for each species and sampling site. The collected fish were anesthetized with menthol and then preserved in $4 \%$ formaldehyde and packed in plastic bags, properly identified for transport to the Laboratory of Ichthyology of the State University of Feira de Santana (UEFS). In the Laboratory, the fishes were identified to the lowest possible taxonomic level and counted. The relative fish abundance (\% 
CPUE) was estimated for each species and sampling site.

Each sampling site was characterized with a set of environmental parameters (Table I). These included geographic positioning, altitude, slope, hydromorphology, habitat features and the physical and chemical water characteristics. Depending on the variable, data was gathered from geographic information systems or measured in situ (Table I).

\section{River typology}

A cluster analysis was performed to group sampling sites according to fish relative abundance (\%CPUE). For this purpose, the squared Euclidean distance was calculated between the sampling sites followed by the application of the Ward grouping method (Ward, 1963). This agglomerative technique is recommended to obtain clusters from environmental and biological data (Cao et al., 1997). Subsequently, the environmental parameters that best explained the biological clustering were identified using a forward stepwise discriminant analysis (McGarigal, 2000). In this type of analysis, a discriminant model is created step by step and at each stage, all variables are reviewed and evaluated to determine which variable will contribute most to discrimination between groups. The data used in the discriminant analysis was log transformed and, in the case of proportions, square root transformed (Underwood, 1997). The variables were selected according to the criteria of the greater F-value to be included in the model, with a minimum value of 1. Finally, a comparison was made between the biological and abiotic grouping (observed vs. predicted grouping) to evaluate the discriminant analysis model adequacy. The analyses were performed with Statistica Version 7.0 software.

\section{RESULTS}

\section{Biological characteristics of the river types}

In the 35 sampling sites, 3316 fish belonging to 47 species and 14 families were captured (Table II). Fish specimens were preserved and registered in the fish division collection of the UEFS Zoology Museum. The dominant species were Astyanax aff. scabripinnis and Astyanax sp., with 1826 and 1135 specimens, respectively. The cluster analysis identified three river groups based on the ichthyofauna (Figure 2). Group 1 was characterized by the exclusive dominance of common species, such as species from the genus Astyanax and Hoplias. Rivers belonging to group 2 were characterized by the presence of accessory species from the genus Geophagus, Hoplerythrinus, Hyphessobrycon, Parotocinclus and 
Rhandia. Group 3 was compose of river supporting rare species of the genus Parotocinclus, Tetragonopterus, Parauchenipterus, Leporinus, Hemigrammus, Cyphocarax, Cichlasoma, Copionodon, and Hypostomus.

\section{Environmental river typology}

Among the 23 environmental variables recorded in this study, 11 were selected by the discriminant analysis model, and five were significant: Altitude, geomorphology, depth, type of vegetation, and latitude (Table III). The classification function resulted in $91 \%$ of well-classified cases and the model characterized rivers with three environmental types, cultivated areas, rupestrian fields and forest areas (Table IV).

\section{DISCUSSION}

In semiarid regions, human population frequently experience irregularly flowing freshwater ecosystems that exhibit unpredictable and high year-to-year variability in precipitation resulting in lengthy periods of drought and floods (Caiola et al., 2001a,b; Ferreira et al., 2007a,b). Man has responded to this hydrological variability with numerous water projects that affect water quantity. These include impoundment of river waters and alterations to channel morphology, mainly for agriculture practices, flood prevention and industrial uses (Fieseler \& Wolter, 2006). In addition, industrial waste and sewage effluents also cause water quality to deteriorate. The Chapada Diamantina region has suffered, historically, from these and other impacts related mainly to the mechanized diamond mining. It is a unique place in the world and, therefore, nature conservation actions including river restoration are needed.

The basis for using biology for aquatic ecosystems monitoring is that human activities that alter physical and chemical processes associated with water resources also modify the resident communities (Esteves \& Valim, 2011). Even though the IBI is applied in different aquatic ecosystems, studies on the analysis of the relationship between these methods and the historical land use are scarce (Oberdorff et al., 2002). Fish based methods to assess ecological quality of running waters have proved to be very useful in the detection of human induced impacts on the aquatic ecosystems. These methods were able to detect, not only water quality impacts, but also environmental disfunctions related with insufficient discharge (Caiola 
et al., 2014; Belmar et al., 2018, 2019). The development of an IBI for the Chapada Diamantina running waters is, thus of great importance.

In the development or adaptation of an IBI, first reference conditions (pristine or least disturbed) are established and then the biotic metrics will measure the deviation regarding present conditions. In most of the adaptations of the IBI, it remains unclear how reference conditions were established (Jaramillo-Villa \& Caramaschi, 2008). The absence of previous studies on the Chapada Diamantina ichthyofauna do not allow the establishment of reference conditions based on historical datasets (Santos \& Caramaschi, 2007; 2011). In these cases of scarce or non-existent historical data, reference conditions can be formulated on the basis of potential fish distribution modelling (Canning 2018; Zogaris et al., 2018) or expert judgement (Virbickas \& Kesminas, 2007; Pardo et al. 2012). In either case, it is much more accurate to formulate reference conditions for homogeneous functional river types. The river typology developed here will allow defining reliable reference conditions for each river type that will assist in the development of a useful IBI for the Chapada Diamantina. This so-called spatially based approach for the development of IBIs, which implies the definition of river typologies prior to the definition of the metrics that constitute the assessment method itself, has been successfully applied in several regions of the world (Sostoa et al. 2004; Turak \& Koop, 2008). This approach has been proven to produce more accurate IBIs in regions with high hydrological stress and characterized by a highly endemic native fish fauna (Segurado et al., 2014). This spatially based approach can be applied to wider areas. Previous attempts to develop fish based assessment methods in Brazil are limited to homogeneous areas such as the upper or mid-course of similar geomorphological rivers (Araujo et al., 2003; Bozzeti \& Schultz, 2004, Casatti et al., 2009; Casatti \& Teresa, 2012).

River typology, like many other ecosystem classifications, is a simplification of nature. It is a static representation of a complex and continuous situation and with a highly dynamic spatial pattern. Moreover, due to zoogeographic aspects it has been shown that relatively undisturbed short river reaches in close proximity to one another may differ greatly with regard to to fish species richness (Turak \& Koop, 2008). Therefore, some typologies established using only abiotic descriptors may not be useful in the subsequent development of IBI fish metrics. Considering that both biological and abiotic variables are included in this typology and that there is a very high concordance between the biological and abiotic river classifications (91\% of well classified cases), it is expected that the future Chapada Diamantina IBI will allow an accurate assessment of the ecological status. Another advantage of this high concordance 
between the fish-based clustering and the abiotic discriminant model, is that there is a high confidence level for the classification of new river stretches that were not sampled in this study. It is important to point out that the objective of this typology is not to describe the biogeography of the fish species from the Chapada Diamantina and, therefore, it cannot be used alone to make accurate predictions of a fish species occurrence in the study area. However, the attribution of any river stretch to an ecological type provides an indication of the fish community composition expected in this stretch.

Although the rivers typology in Chapada Diamantina is an important first step for the development of an IBI suitable to assess the ecological status of running waters in this region, there are still some weaknesses that should be overcome. In the present study, many fishes were identified only on a generic level, indicating the necessity for investment in studies on the ichthyofauna of the Paraguaçu basin. Since the 1990's, studies on the systematic and ecology of ichthyofauna from the Chapada Diamantina have became more frequent. These studies have described, around 20 news fish species. Moreover, the information on the life history traits of most species is scarce (Jaramillo-Villa \& Caramaschi, 2008). This lack of information is common due to the high diversity of tropical fishes. This is a challenge for the development of IBIs in the Neotropical realm mainly because IBI fish metrics are based on functional groups and, in order to attribute functional guilds to fish species, it is necessary to know life history and other ecological traits.

\section{ACKNOWLEDGMENTS}

We thank Prof. Erica Caramaschi (UFRJ) for her support in all stages of this work. To Marconi Sena (UEFS) and Dr. Marcelo Brito (UFS) for their constant support in field activities. To Ronaldo Pinheiro (INMA) for the map elaboration. To Dr. Neil Duncan (IRTA) for reviewing the English language of the manuscript. To CNPq for the ACAS postdoctoral scholarship (150649/2008-8) and for the grant approval of the Universal Project which provided financial resources to perform this study. To the Fundação de Amparo à Pesquisa do Estado da Bahia (FAPESB) for the financial support through the Social and Environmental Technologies call (TSC0007/2009). To the Fundación Carolina for the ACAS scholarship (Beca de Formación Permanente) to perform a research stay at IRTA, Catalonia.

\section{REFERENCES}

Angermeier, P. L. \& J. R. Karr, 1986. Applying an index of biotic integrity based on stream-fish 
communities: considerations in sampling and interpretation. North American Journal of Fisheries Management 6: 418 - 429.

Araújo, F. G. I. Fichberg, B. C. T. Pinto \& M. G. Peixoto, 2003. A preliminary index of biotic integrity for monitoring the condition of the Rio Paraiba do Sul, southeast Brazil. Environmental Management 32: $516-526$.

Belmar, O., C. Ibáñez, A. Forner, N. Caiola, 2019. The influence of flow regime on ecological quality, bird diversity, and shellfish fisheries in a Lowland Mediterranean River and its coastal area. Water, 11(5): 918.

Belmar, O., N. Vila-Martínez, C. Ibáñez, N. Caiola, 2018. Linking fish-based biological indicators with hydrological dynamics in a Mediterranean river: Relevance for environmental flow regimes. Ecological indicators, 95: 492-501.

Bozzetti, M. \& U. H. SCHULZ, 2004. An index of biotic integrity based on fish assemblages for subtropical streams in southern Brazil. Hydrobiologia 529:133-144.

Caiola, N., C. Ibáñez, J. Verdú, A. Munné, 2014. Effects of flow regulation on the establishment of alien fish species: A community structure approach to biological validation of environmental flows. Ecological indicators, 45: 598-604.

Caiola, N., M. J. Vargas, A. Sostoa, 2001a. Feeding ecology of the endangered Valencia toothcarp, Valencia hispanica (Actinopterygii: Valenciidae). Hydrobiologia, 448, 97-105.

Caiola, N., M. J. Vargas, A. Sostoa, 2001b. Life history pattern of the endangered Valencia toothcarp, Valencia hispanica (Actinopterygii: Valenciidae) and its implications for conservation. Archiv für Hydrobiologie, 150, 473-489.

Canning, A. D., 2018. Predicting New Zealand riverine fish reference assemblages. PeerJ, 6, e4890.

Casatti, L., P. F. Ferreira \& F. Langeani, 2009. A fish-based biotic integrity index for assessment of lowland streams in southeastern Brazil, Hydrobiologia 623:173-189.

Casatti, L. \& F. B. Teresa, 2012. A fish-based biotic integrity index for assessment of lowland streams in southeastern Brazil. Acta Limnologica Brasiliensia 24(4): 339-350.

Cao, Y., A. Bark, \& W. Williams, 1997. A comparison of clustering methods for river benthic community analysis. Hydrobiologia 347: $24-40$.

CPRM, Companhia de Pesquisa de Recursos Minerais. IBAMA, 1994. Projeto Chapada Diamantina BA: Informações básicas para a gestão territorial: Diagnóstico do meio físico e da vegetação. 
Salvador, BA.

Daniels, R.A., K. Riva-Murray, D. B. Halliwell, D. L. Vana-Miller \& M.D. Bilger, 2002. An index of biological integrity for northern mid-Atlantic slope drainages. Transactions of the American Fisheries Society 131: 1044-1060.

Esteves, K. E. \& A. C. Valim, 2011. Development of an index of biotic integrity based on fish communities to assess the effects of rural and urban land uses on a stream in southeastern Brazil. International Review of Hydrobiology 96: 296-317.

European Commission. 2000. Directive (2000/60/EC). Establishing a framework for community action in the field of water policy. Pages 1-72 in Official Journal of the European Communities (22/12/2000) L327.

Fausch, K.D., J.R. Karr, and P.R. Yant, 1984. Regional applications of an index of biotic integrity based on stream fish communities. Transactions of the North American Fisheries Society 113: 39-55.

Ferreira, T., N. Caiola, F. Casals, J. M. Oliveira, A. Sostoa, 2007a. Assessing perturbation of river fish communities in the Iberian Ecoregion. Fisheries Management and Ecology, 14(6): 519-530.

Ferreira, T., J. Oliveira, N. Caiola, A. Sostoa, F. Casals, R. Cortes, A. Economou, S. Zogaris, D. Garcia-Jalon \& M. Ilhéu, 2007b. Ecological traits of fish assemblages from Mediterranean Europe and their responses to human disturbance. Fisheries Management \& Ecology 14: 473-481.

Ganasan, V. \& R. M. Hughes, 1998. Application of an index of biological integrity to fish assemblages of the rivers Khan and Kshipra, India. Freshwater Biology 40: 367-383.

Giulietti A. M., J. R. Pirani, \& R. M. Harley, 1997. Espinhaço Range Region, Eastern Brazil. In: Davis SD, Heywood VH, Villa-Lobos J, Hamilton AC (eds) Centres of plant diversity. A guide and strategy for their conservation, vol 3. The Americas. IUCN Publication Unity, Cambridge, pp 397-404.

Harley R. M., 1995. Introduction. In: Stannard BL (ed) Flora of the Pico das Almas, Chapada Diamantina, Brazil. Royal Botanic Gardens, Kew, p. 1-42

Hughes, R. M. \& J. R. Gammon, 1987. Longitudinal changes in fish assemblages and water quality in the Willamette River, Oregon. Transactions of the American Fisheries Society 116: 196-209.

Jaramillo-Villa, U. \& E. P. Caramachi, 2008. Índices de integridade biótica usando peixes de água doce: Uso nas regiões tropical e subtropical. Oecologia Brasiliensis 12(3): 442-462. 
Joy, M. K. \& R. G. Death, 2004 Application of the index of biotic integrity methodology to New Zealand freshwater fish communities. Environ. Manage 34:415-428.

Kamdem Toham A. \& G. G. Teugels, 1999. First data on an index of biotic integrity (IBI) based on fish assemblages for the assessment of the impact of deforestation in a tropical West African river system. Hydrobiologia, 397:29-38.

Karr, J. R., 1981. Assessment of biotic integrity using fish communities. Fisheries 6(6): 21-27.

Karr, J. R., 1991. Biological integrity: a long-neglected aspect of water resource management. Ecological Applications 1: 66-84.

Karr, J. R., D. R. Dudley, 1981. Ecological perspective on water quality goals. Environmental management, 5(1): 55-68.

Karr, J. R., K. D. Fausch, P. L. Angermeier, P. R. Yant, I. J. Schlosser, 1986. Assessing Biological Integrity in Running Waters: A Method and Its Rationale. Special Publication 5. Illinois Natural History Survey, Champaign.

Lyons, J., 1992. Using the index of biotic integrity (IBI) to measure environmental quality in warm water streams of Wisconsin", General Technical Report, NC-149, North Central Forest Experiment Station, U.S. Forest Service, St. Paul, Minnesota.

McGarigal K., S. Cushman, \& S. Stafford, 2000. Multivariate Statistics for Wildlife and Ecology Research. New York: Springer.

De Pinna, M. C. C., 1992. A new subfamily of Trichomycteridae (Teleostei, Siluriformes), lower loricarioid relationships and a discussion on the impact of additional taxa for phylogenetic analysis. Zoological Journal of the Linnean Society 106: 175-229.

Oberdorff, F. T. \& R. M. Hughes, 1992. Modification of an index of biotic integrity based on fish assemblages to characterize rivers of the Seine Basin. Hydrobiologia 228 (2), 117-130.

Pardo, I., C.Gómez-Rodríguez, J.G. Wasson, R. Owen, W. van de Bund, M. Kelly, N. Mengin, 2012. The European reference condition concept: a scientific and technical approach to identify minimallyimpacted river ecosystems. Science of the Total Environment, 420: 33-42.

Ribeiro, O. M. \& J. Zuanon, 2006. Comparação da eficiência de dois métodos de coleta de peixes em igarapés de terra firme da Amazônia Central. Acta Amazonica 36: 389 -394.

Rodríguez-Olarte, D., A. Amaro, J. Coronel, \& D. C. B. Taphorn, 2006. Integrity of fluvial fish communities is subject to environmental gradients in mountain streams, Sierra de Aroa, north 
Caribbean coast, Venezuela. Neotrop. Ichthyol. 4(3):319-328.

Roset, N., G. Grenouillet, D. Goffaux, D. Pont, \& P. Kestemont, 2007. A review of exiting fish assemblage indicators and methodologies. Fisheries Management and Ecology 14: 393-405.

Santos, A. C. A. \& E. P. Caramaschi, 2007. Composition and Seasonal Variation of the Ichthyofauna from Upper Rio Paraguaçu (Chapada Diamantina, Bahia, Brazil). Brazilian Archives of Biology and Technology 50(4): 663-672.

Santos, A. C. A. \& E. P. Caramaschi, 2011. Temporal variation in fish composition and abundance in a perennial tributary of the Rio Paraguaçu, a little-known drainage in the Brazilian semi-arid region. Neotropical Ichthyology 9(1): 153-160.

Segurado P., N. Caiola, D. Pont, J. M. Oliveira, O. Delaigue \& M. T. Ferreira, 2014. Comparability of fish-based ecological quality assessments for geographically distinct Iberian regions. Sci Total Environ 476: 785-794.

Schmutz, S., A. Melcher, C. Frangez, G. Haidvogl, U. Beier, J. Böhmer, J . Breine, I . Simoens, N. Caiola, A. De Sostoa, M. T . Ferreira, J. Oliveira, G. Grenouillet, D. Goffaux, J . J . De Leeuw, R . A . A . Noble, N. Roset, T . Virbickas, 2007. Spatially based methods to assess the ecological status of riverine fish assemblages in European ecoregions. Fisheries management and Ecology 14(6): 441-452.

Smogor, R. A. \& P. L. Angermeier, 2001. Determining a regional framework for assessing the biotic integrity of Virginia stream Transactions of the American Fisheries Society 130(1): 18-35.

Strange, R.M., 1998. Historical biogeography, ecology and fish distribution: conceptual issues for establishing IBI criteria. In: T.P. Simon (ed.) Assessment Approaches for Estimating Biological Integrity using Fish Assemblages. Boca Raton, FL: Lewis Publishers, pp. 65-78.

Turak E. \& K. Koop, 2008. Multi-attribute ecological river typology for assessing the ecological condition and conservation planning. Hydrobiologia 603: 83-104.

Oberdorff, T., D. Pont, B. Hugueny \& J. P. Porcher, 2002. Development and validation of a fish-based index for the assessment of 'river health' in France. Freshwater Biol 47:1720-1734.

Sostoa, A., N. Caiola, \& F. Casals, 2004. A New IBI (IBICAT) for local application of the E. U. Water Framework Directive. p. 187-191. In: Fifth International Symposium on Ecohydraulics. Aquatic Habitats: Analysis \& Restoration. Madrid. 2004.

Steedman, R. J., 1988. Modification and assessment of an index of biotic integrity to quantify stream quality in southern Ontario. Canadian Journal of Fisheries and Aquatic Sciences 45: 492-501. 
Uieda, V. S. \& R. M. C. Castro, 1999. Coleta e fixação de peixes de riachos. In: Caramaschi, E. P.; Mazzoni, R. \& P. R. Peres-Neto, (Eds.). Ecologia de Peixes de Riachos, Série Oecologia Brasiliensis. Vol. VI. PPGE-UFRJ, Rio de Janeiro, Brasil. p. 1-22.

Underwood, A. J., 1997. Experiments in ecology: their logical design and interpretation using analysis of varianza. Cambridge University Press, Cambridge, United Kingdom. 504 pp.

Virbickas T., V. Kesminas, 2007. Development of fish-based assessment method for the ecological status of rivers in the Baltic region. Fisheries management and ecology, 14(6): 531-539.

Ward, J. H. Jr., 1963. "Hierarchical Grouping to Optimize an Objective Function", Journal of the American Statistical Association 58: 236-244.

Zogaris, S., V. Tachos, A.N. Economou, Y. Chatzinikolaou, N. Koutsikos, S. Schmutz, 2018. A modelbased fish bioassessment index for Eastern Mediterranean rivers: Application in a biogeographically diverse area. Science of the Total Environment, 622: 676-689. 
Table I. Abiotic variables used in the analysis and the methods employed for the data gathering.

\begin{tabular}{|c|c|}
\hline Variable & Method \\
\hline $\mathrm{pH}$ & Field measurement with U-50 Multiparameter - HORIBA \\
\hline Electrical conductivity $(\mu \mathrm{S})$ & Field measurement with U-50 Multiparameter - HORIBA \\
\hline Dissolved Oxygen (mg/l) & Field measurement with U-50 Multiparameter - HORIBA \\
\hline Water temperature $\left(\mathrm{C}^{0}\right)$ & Field measurement with thermometer \\
\hline Air temperature $\left(\mathrm{C}^{0}\right)$ & Field measurement with thermometer \\
\hline Transparence $(\mathrm{m})$ & Field measurement with Secchi disc \\
\hline Dominant substrate & $\%$ Cover of silt, sand, gravel, pebble, stone or rock \\
\hline Dominant mesohabitat & $\%$ of pool, table or riffle \\
\hline Riparian vegetation & $\%$ Cover of \\
\hline Dominant vegetation & $\%$ Cover of Trees, shrubs, and herbs \\
\hline Aquatic vegetation & $\%$ of \\
\hline Water color & Assessed visually in the field \\
\hline River order & Determined from maps \\
\hline Average Flow $\left(\mathrm{m}^{3} / \mathrm{s}\right)$ & Field measurement with fluxometer \\
\hline Average river width (m) & Average of the width of water assessed visually in the field \\
\hline Average river depth (m) & Average of the depth of water assessed visually in the field \\
\hline Elevation (m) & Determined from GPS \\
\hline Mean annual rainfall $(\mathrm{mm})$ & Determined from GIS \\
\hline Geology & Determined from GIS \\
\hline Vegetation type & Determined from GIS \\
\hline Geomorphology & Determined from GIS \\
\hline Soil & Determined from GIS \\
\hline Latitude, longitude & Determined from GPS \\
\hline
\end{tabular}


Table II. List of species, families, and vernacular names of fishes recorded in Chapada Diamantina region.

\section{Taxonomic List}

Vernacular Names

CHARACIFORMES

PARODONTIDAE

Apareiodon itapicuruensis Eigenmann \& Henn

Canivete

CURIMATIDAE

Cyphocharax gilberti (Quoy \& Gaimard, 1824)

Sabarona

ANOSTOMIDAE

Leporinus bahiensis Steindachner, 1875

Piau

\section{CRENUCHIDAE}

Characidium cf. bahiensis Almeida, 1971

Piaba-charuto

Characidium cf. bimaculatum Fowler, 1941

Piaba-charuto

Characidium cf. zebra Eigenmann 1909

Piaba-charuto

Characidium clistenesi Melo \& Espíndola, 2016

Piaba-charuto

\section{CHARACIDAE}

INCERTAE SEDIS

Astyanax aff. scabripinnis

Piaba

Astyanax gr. bimaculatus (Linaeus, 1758)

Piaba-dedo-de-moça

Astyanax cf. fasciatus (Cuvier, 1819)

Piaba

Astyanax sp.1

Piaba

Astyanax sp.2

Piaba

Astyanax sp.3

Piaba

Astyanax sp.4

Piaba

Hyphessobrycon negodagua Lima \& Gerhard 2001

Piaba

Hemigrammus marginatus Ellis, 1911

Piaba

Knodus sp.

Piaba

Moenkhausia diamantina Benine, Castro \& Santos 2007

Piaba

Myxiops aphos Zanata \& Akama, 2004

Piaba 
Piabina argentea Reinhardt, 1867

Piaba

Characinae

Phenacogaster franciscoensis Eigenmann 1911

Piaba

CHEIRODONTINAE

Serrapinnus heterodon (Eigenmann, 1915)

Piaba

TETRAGONOPTERINAE

Tetragonopterus chalceus Agassiz, 1829

Piaba-zoião

\section{ERYTHRINIDAE}

Hoplerytrinus unitaeniatus (Schneider, 1829)

Uiu

Hoplias cf lacerdae, Ribeiro, 1908

Traira-cabeça-fina

Hoplias malabaricus (Bloch, 1794)

Traira-cabeça-de-lama

\section{SILURIFORMES}

TRICHOMYCTERIDAE

Copionodon pecten de Pinna, 1992

Jundiá

Trichomycterus gr. brasiliensis Lutken, 1874

Jundiá

Trichomycterus sp.

Jundiá

\section{CALLICHTHYIDAE}

Aspidoras psammatides Britto, Lima \& Santos, 2005

Cascudinho

Corydoras cf. garbei (Ihering, 1910)

Cascudinho

\section{LORICARIIDAE}

Hypostomus crhysostiktos Birindelli \& Zanata, 2007

Cari

Hypostomus sp.

Cari

Parotocinclus adamanteus Pereira, Santos, de Pinna \&Reis 2019

Cascudinho

Parotocinclus sp.

Cascudinho

HEPTAPTERIDAE

Heptapterus sp.

Jundiá

Pimelodella sp.

Jundiá

Rhamdia cf. quelen (Quoy \& Gaimard, 1824)

Jundiá

\section{AUCHENIPTERIDAE}

Parauchenipterus galeatus Linnaeus, 1766

Cumbá/molé/bate-papo 


\section{GYMNOTIFORMES}

GYMNOTIDAE

Gymnotus gr. carapo Linnaeus, 1758

Peixe-cobra

\section{CYPRINODONTIFORMES}

POECILIIDAE

Pamphorichthys hollandi (Henn, 1916)

Barrigudinho, pariviva

Pamphorichthys sp.n

Barrigudinho, pariviva

Pamphorichthys sp.

Barrigudinho, pariviva

Poecilia reticulata Peters, 1859

Barrigudinho, pariviva

\section{PERCIFORMES}

CICHLIDAE

Cichlasoma sanctifranciscense

Corró-branco

Cichlasoma sp.

Corró

Geophagus diamantinensis Mattos, Costa \& Santos, 2015

Corró 
Table III. Mean, Standard deviation (SD) and Willk's Lambda generated by discriminant analysis showing separation of groups and environmental variables for the Chapada Diamantina rivers, BA.

\begin{tabular}{|l|l|l|l|l|l|l|}
\hline Variable & Mean & SD & Wilks & Partial & F & P \\
\hline PH & 5,57 & 1,38 & 0,21 & 0,87 & 1,60 & 0,2239 \\
\hline Altitude $(\mathrm{m})$ & 692,81 & 269,81 & 0,45 & 0,41 & 15,67 & $0,0001^{*}$ \\
\hline Conductivity $(\mu \mathrm{S} / \mathrm{cm})$ & 0,06 & 0,11 & 0,22 & 0,87 & 1,71 & 0,2036 \\
\hline Geomorphology & 3,03 & 1,33 & 0,29 & 0,65 & 6,02 & $0,0008^{*}$ \\
\hline Mesohabitat & 2,22 & 0,69 & 0,21 & 0,90 & 1,25 & 0,3057 \\
\hline Depth (cm) & 36,11 & 19,52 & 0,27 & 0,68 & 5,15 & $0,0147^{*}$ \\
\hline Type of vegetation & 2,75 & 1,84 & 0,27 & 0,69 & 4,99 & $0,0163^{*}$ \\
\hline Latitude $(U T M)$ & 241358,00 & 13757,30 & 0,26 & 0,73 & 4,04 & $0,0321^{*}$ \\
\hline Soil & & & & & & \\
\hline Vegetal cover & 6,25 & 1,23 & 0,22 & 0,86 & 1,78 & 0,1924 \\
\hline Width (m) & 7,16 & 5,38 & 0,22 & 0,84 & 2,07 & 0,1498 \\
\hline
\end{tabular}

* = Significant 
Table IV. Environmental descriptors for the Chapada Diamantina Rivers.

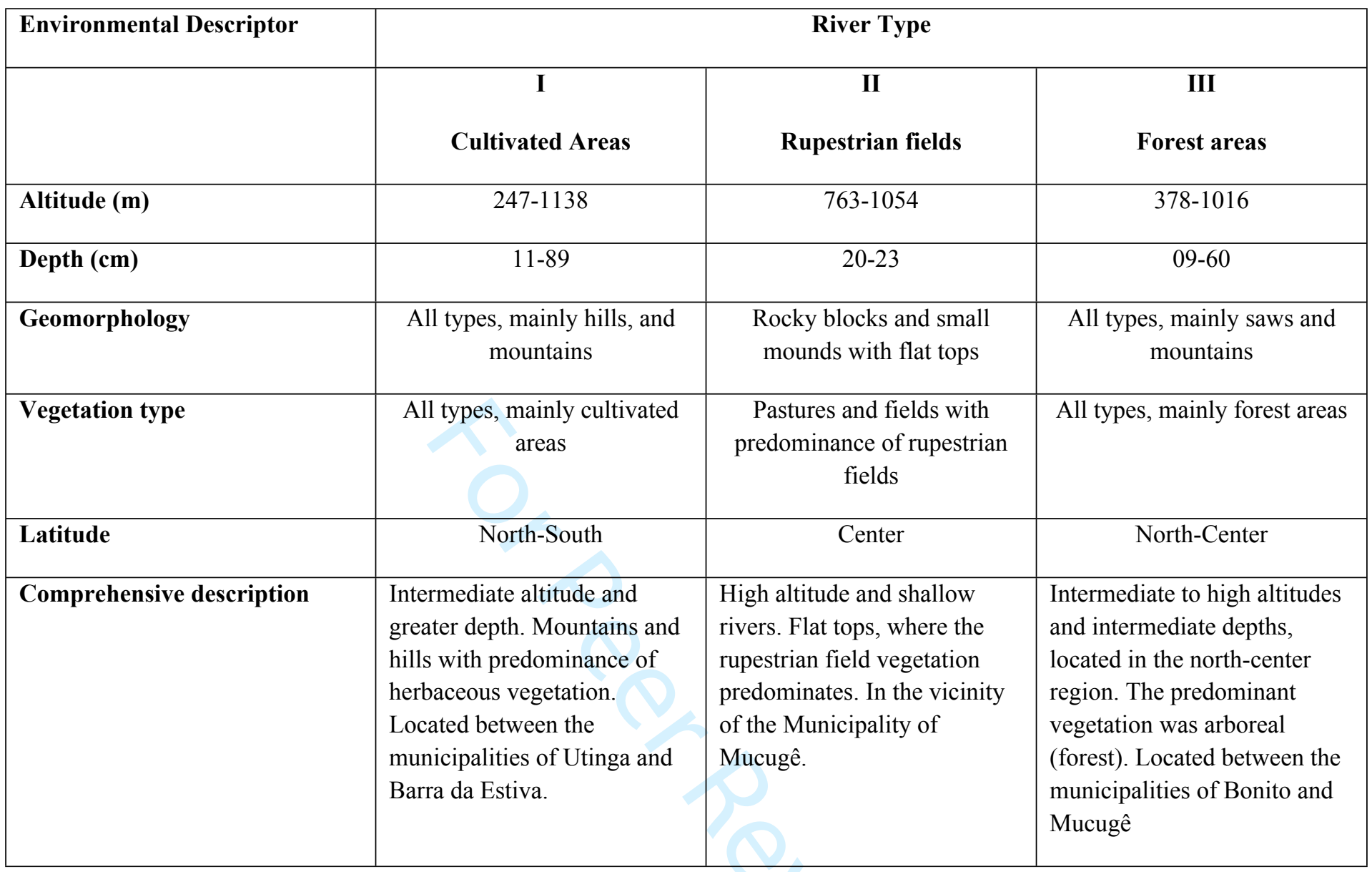




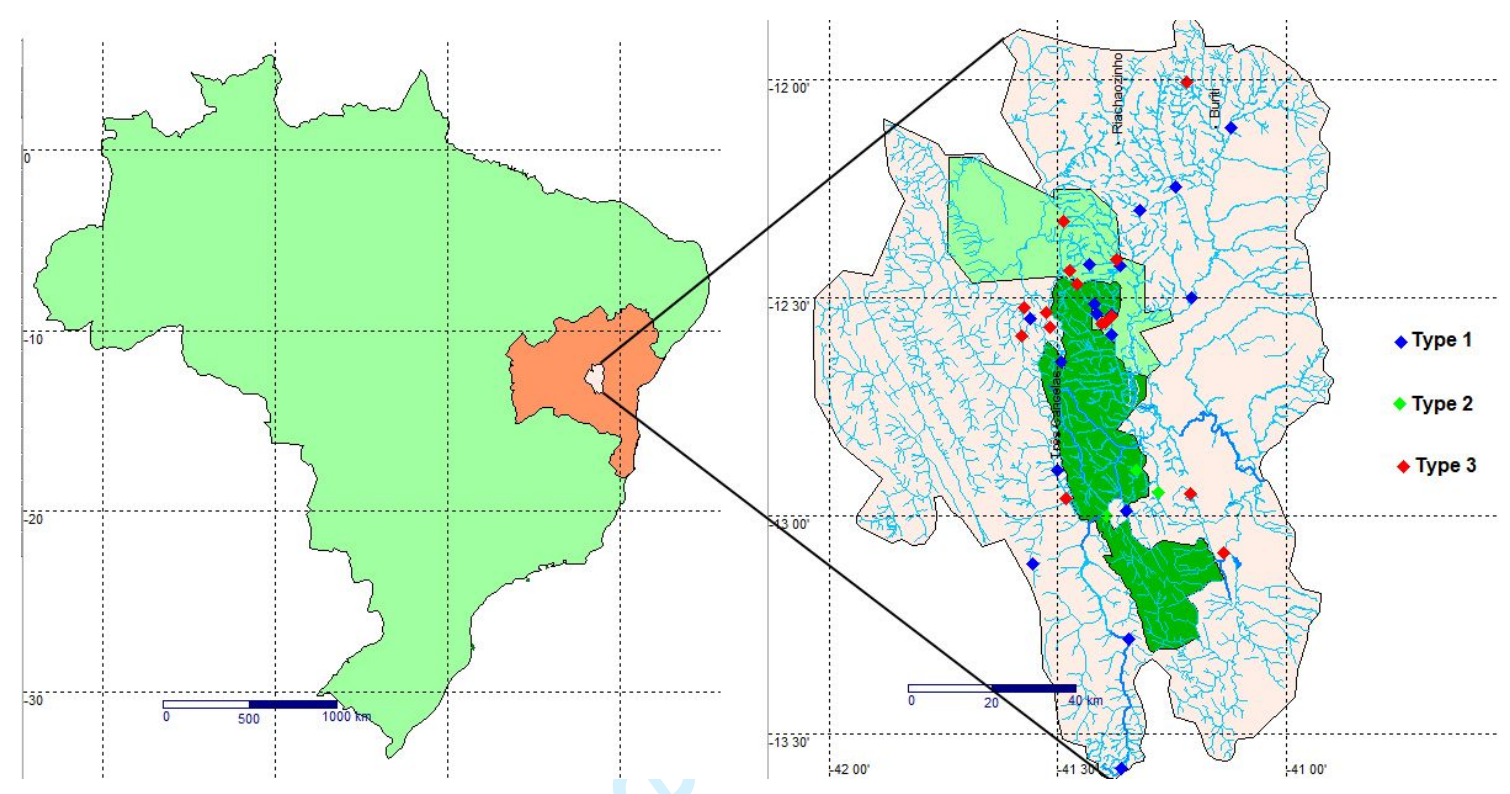




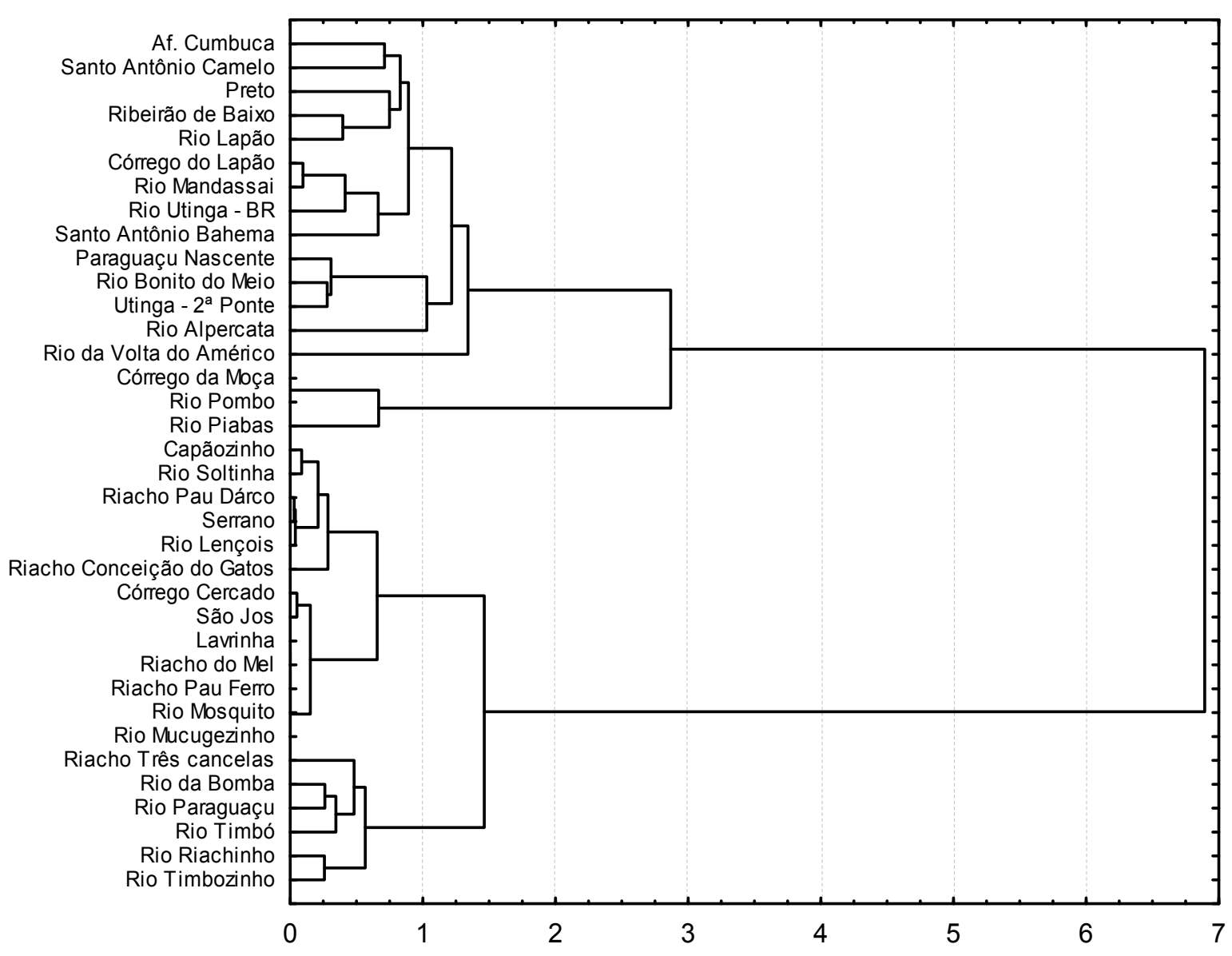

